\title{
What is the Top Priority on Climate Change?
}

The latest version of this paper, and related material, is at www.paulklemperer.org

Paul Klemperer

Edgeworth Professor of Economics, Oxford University

this draft January 2009

Int Tel: +44 1865278588

paul.klemperer@economics.ox.ac.uk

Nuffield College, Oxford, OX1 1NF, England

DRAFT: PLEASE SEND COMMENTS

\begin{abstract}
What should be the West's top priority for climate-change policy?

This article is a revised and updated version of my talk to the Potsdam Global Sustainability Symposium (which drafted the "Potsdam Declaration" presented to the 2007 UN Climate Change Conference in Bali).
\end{abstract}

Acknowledgements: I have no special expertise on the scientific aspects of climate change. I am very grateful to all those who have tried to educate me, but they are not responsible for remaining errors. I am particularly grateful to many friends and colleagues, including Jeremy Bulow, Ken Coutts, Dave Frame, Steven Fries, Chris Goodall, Tim Harford, Cameron Hepburn, Cath Howdle, Max Tse, and especially Elizabeth Baldwin, for numerous helpful comments and suggestions on the current paper; Elizabeth Baldwin also provided expert research assistance for it.

(C) Paul Klemperer 2007, 2008, 2009 
Action on climate change is urgent. Substantial uncertainty about the importance of the problem remains, ${ }^{1}$ but this uncertainty means we should worry more, not less -because while things may not be as bad as the most likely scenarios suggest, outcomes might also be a lot worse. ${ }^{2}$ What, therefore, should be the West's top priority for policy?

The critical issue

The critical issue is that no strategy will work unless it is consistent with developing countries' continued economic growth. ${ }^{3}$ So we are unlikely to be able to reduce the use of 'dirty' energy enough - either through carbon taxes or through a 'cap and trade' permit system - unless we can find a cheap, clean, substitute. And that requires innovation.

Developing countries are not going to give up the immediate aspirations of their (often growing) populations for climate-change benefits that are largely in the future. Worrying about preserving the environment for our great-grandchildren is a luxury developing nations do not have.

China, for example, stresses even in the Foreword to its National Climate Change Programme that 'economic and social development and poverty eradication are [its] first and overriding priorities'. ${ }^{4}$ Whether or not this is morally right (it may be justified for a developing country) is irrelevant. It is a political imperative for the leadership of a country in which, according to the latest figures, about 200 million people live below the World Bank's 'dollar-a-day' poverty line, and 100 million are illiterate. ${ }^{5}$

\footnotetext{
1 See Klemperer (2007), and also, e.g., Table 1 of Nick Stern's paper in this volume.

2 See Klemperer (2008a), and also Topic 6.2 in the IPCC's $4^{\text {th }}$ Synthesis Report, 2007.

3 This point applies across the polluting sectors, including, for example, deforestation (see, e.g., Angelsen and Kaimowitz, 1999, Lambin et al, 2001), but we focus here on energy, where policy may be most essential.

${ }^{4}$ However, the Chinese government is merely quoting the United Nations Framework Convention on Climate Change's statement that 'economic and social development and poverty eradication are the first and overriding priorities of the developing country Parties' (article 4, paragraph 7).

${ }^{5}$ This is not, of course, to suggest the Chinese are less 'moral' than the West - on the contrary, their value system may place more weight on, and their culture offer more support to, intergenerational justice. And, of course, many people from all parts of the world are concerned about the effects of climate change on current as well as future generations, and regard environmental protection as a
} 
Thus, although China has probably now overtaken the US to become the world's number one polluting nation, ${ }^{6}$ its officials emphasise that it has no obligation to cut emissions under the Kyoto protocol. And it seems unlikely to do so voluntarily, at least on the scale required -- consider, for example, China's recently-announced plan to build 97 new airports in the next 12 years (while the UK currently agonises about whether to build a single extra runway at Heathrow!).

\section{The challenge}

Much recent research suggests that we need to stabilise greenhouse-gas concentrations below 400 parts per million carbon dioxide equivalent, if we wish 'to preserve a planet similar to that on which civilization developed and to which life on Earth is adapted'. Indeed, the IPCC says stabilisation at around 380ppm $\mathrm{CO}_{2}$ equivalent would yield a more than $20 \%$ probability that global warming will exceed $2^{\circ} \mathrm{C}$, the level that is commonly referred to as the threshold for 'dangerous' warming (and the EU has adopted the target of keeping the temperature increase below this level). ${ }^{8}$

necessity, not a luxury. (In China, Pan Yue, deputy director of China's state Environmental Protection Administration, who was named the New Statesman's 'person of the year 2007', is just one notable example.)

We focus especially on China among the rapidly-developing countries, because of its size, and because of our focus on energy use; other countries are obviously especially important in the context of deforestation

Keidel (2007) estimated 300 million Chinese were below the 'dollar-a-day' poverty line (which is calculated on the basis of 'purchasing power parity' exchange rates which compare prices across different countries), but Chen and Ravallion (2008)'s more recent work suggests an estimate of 200 million for 2005, and that this number is rapidly declining. The World Bank (2008) give an illiteracy figure of 100 million for 2000; the UN (2007) gives an estimate of 130 million for 2003.

${ }^{6}$ See Auffhammer and Carson (2007). Note also that China's energy intensity is 1.5 times the global average (World Bank (2008) figure for 2005).

${ }^{7}$ Hansen et al. (2008) write that achieving this objective requires stabilization at $350 \mathrm{ppm} \mathrm{CO}_{2}$; including all greenhouse gases, this would correspond to a little under $400 \mathrm{ppm}$ ' $\mathrm{CO}_{2}$ equivalent' if today's relative atmospheric concentrations of the different greenhouse gases were maintained

The current levels are 380ppm $\mathrm{CO}_{2}$ and 430ppm $\mathrm{CO}_{2}$ equivalent (Stern 2007, Section 1.2).

The campaign to set a target of 350ppm endorsed by, among others, Al Gore at the United Nations Climate Change Conference in Poznań, 2008 (see

http://www.un.org/climatechange/blog/2008/121208.shtml) is based upon Hansen et al. (2008), and so refers to levels of $\mathrm{CO}_{2}$ alone, but most current debate refers to $\mathrm{CO}_{2}$ equivalent levels.

${ }^{8}$ See IPCC (2007) Table 3.9, Working Group III Report 'Mitigation of Climate Change'. An estimated probability of $20 \%$ is obtained at $378 \mathrm{ppm}$ even using calculations that 'do not take into account the full range of bio-geophysical feedbacks that may occur'. 
Perhaps these estimates are pessimistic. But even stabilising greenhouse gas concentrations at $500 \mathrm{ppm} \mathrm{CO}_{2}$ equivalent (so temperature increases above $2{ }^{\circ} \mathrm{C}$ would very likely ${ }^{9}$ ) requires a roughly 50\% reduction in greenhouse-gas emissions by 2050 . Allowing for population growth, this requires a two-thirds fall in per-capita emissions to about 2-2.5 tonnes $\mathrm{CO}_{2}$ equivalent by that date. ${ }^{10}$

The United States, Canada and Australia each now emit well over 20 tonnes $\mathrm{CO}_{2}$ equivalent per head, and the EU and Japan both emit a little above 10 tonnes per head. However, there are signs that these regions may reduce their emissions, because their already-rich populations can afford to worry about their children and grandchildren.

India is still below 2 tonnes of $\mathrm{CO}_{2}$ equivalent emissions per head (and most of subSaharan Africa is well below 1 tonne $\mathrm{CO}_{2}$ equivalent).

But China and several other rapidly-developing countries already emit more than 6 tonnes per head. ${ }^{11}$ So the key challenge is: how do we persuade countries like China to more than halve their emissions when they are so focused on economic growth?

The claim that temperature increases should not exceed $2^{\circ} \mathrm{C}$ above pre-industrial levels to prevent 'dangerous' warming is now routine in official documents (see, e.g., EU (2005)) as well as the media.

${ }^{9}$ Stabilisation at $500 \mathrm{ppm} \mathrm{CO}_{2}$ equivalent yields a temperature increase above $2{ }^{\circ} \mathrm{C}$ in the vast majority of scenarios according to IPCC (2007, Figure 3.38, page 228), and with probability 48-96\% depending on the model used, according to Stern (2007, Box 8.1). Possible emissions pathways, and the associated risks, are discussed extensively in the eight articles forming Section VI of Schellnhuber et al. (2006).

${ }^{10}$ Stabilisation at $500 \mathrm{ppm} \mathrm{CO}_{2}$ equivalent is thought to require global emissions to be reduced to about 20 gigatonnes by 2050 , at which date the global population is projected to be about 9 billion (Stern 2008).

The scale of the challenge is illustrated by the fact that the latest edition of Shell's (2008) highlyrespected Energy Scenarios implies $650 \mathrm{ppm}$ is an optimistic outcome, and that $1000 \mathrm{ppm}$ or more is also plausible - see Prinn et al. (2008) which analyses a range of reputable emissions scenarios and find all lie between 550 and $1780 \mathrm{ppm}$ in 2100 .

The UK has committed to cut its emissions by $80 \%$ by 2050 to reduce them to between 2.1 and 2.6 tonnes per person (Committee on Climate Change Report 2008).

${ }^{11}$ China's 2006 emissions are estimated to be 6.0 tonnes $\mathrm{CO}_{2}$ equivalent per head. Other large rapidlydeveloping countries with high emissions include Turkey (5.7 tonnes per head), Mexico (6.4 tonnes per head), South Africa (10.6 tonnes per head), the Russian Federation (15.4 tonnes per head), Brazil (5.4 tonnes per head counting conventionally, plus 7.25 tonnes per head extra due to land use change, i.e., deforestation) and Indonesia (2.7 tonnes per head conventionally plus 11.5 tonnes per head due to land use change). All the national per-capita emissions figures in this section are Ecofys' (2008) estimates for 2006 
The West has a little leverage: in particular, the French President Nicolas Sarkozy was right to suggest that the EU threaten to tax imports from countries that have neither a carbon tax nor a cap and trade permit system. ${ }^{12}$ If the threat were carried out, and the EU taxed imports' embodied carbon emissions at a rate equal to the price of an EU Allowance, this would be equivalent to introducing these countries' export sectors into the EU's permit system, and would reduce emissions in exactly the same way.

Taxing 'dirty' imports would have other advantages too: it would reduce emitters' incentives to flee the EU for laxer jurisdictions, ${ }^{13}$ it would solve any problem of EU firms being disadvantaged relative to non-EU competitors; and it would therefore also greatly weaken the case for giving free permits to firms, ${ }^{14}$ thus enhancing the EU's ability to raise revenues for other climate change mitigation activities.

Many economists argue that import taxes undermine free trade. They are wrong in theory because the absence of any charge for carbon emissions is effectively a subsidy, which the import taxes simply compensate for. And they are also wrong to argue this in practice, because we should care more about carbon emissions than about the health of the WTO.

Of course, the practical problems of implementation would be substantial. So we would very much hope never to have to carry out this threat. But if the EU promised not to tax imports from countries that introduced their own carbon taxes or permit systems for their exports, many countries would likely introduce these things; the exporting country, rather than the EU, would then collect the revenues from the taxes or permit sales. And having introduced tax or permit systems for exports (and

\footnotetext{
${ }^{12}$ See, e.g., the International Business Times, 15 January 2008.

${ }^{13}$ This incentive can be exaggerated. It operates mostly in the long run, and is mitigated by the expectation of future carbon regulation in developing countries.

${ }^{14}$ Witness the comment of Sigmar Gabriel, environment minister in justifying Germany's recent backtracking on the principle of full auctioning of permits: 'As long as European companies are governed by stricter climate protection regulations than their competitors in countries like China, we have to seek to establish special rules,' (Financial Times, September 22 2008).

Unless there is substantial foreign competition, giving permits to companies free is an unnecessary and improper handout of windfall profits, since consumer prices rise to reflect permits' value, however they are allocated - see Binmore and Klemperer (2002, section 2), Fries (2008), Klemperer (2004, 2008b).
} 
benefited from the revenues), developing countries might later extend them to other parts of their economies.

However, even China's substantial export sector represents only around one third of its GDP, and not much more than half of its exports go to developed-world countries that might plausibly impose an import tax. ${ }^{15}$ But although the West can use other 'punishments' too, such as excluding uncooperative countries from international organizations and sporting events, encouraging consumer boycotts, etc., ${ }^{16}$ the bottom line is that it has only limited influence over the developing world.

China, in particular, seems unlikely to incur significant abatement costs unless it is compensated; this is probably the binding constraint on any global deal. (India matters hugely too, of course, but its per-capita emissions are so much lower that it will probably participate in any agreement that China will accept. ${ }^{17}$ )

\section{The need for more $R \& D$}

\section{What follows?}

First, whether we like it or not, China (and India and others) are going to continue to develop nuclear energy. So unless the West continues to develop it too, the safety and storage and handling issues will be resolved in developing countries, in many of which there is both less democratic accountability than in Europe and the US, and also more pressure to take shortcuts than in richer countries. ${ }^{18}$

\footnotetext{
${ }^{15}$ The developed world (largely EU, US, Japan, Canada, and Australia) accounts for about five eighths of China's exports. About $40 \%$ of this total goes to the EU, and a similar volume goes to the US. See IMF (2008), data for 2007, for the export figures in this paragraph, which are calculated using nominal exchange rates (purchasing power parity rates are substantially different); using nominal values, China's exports 'are on average no more or less carbon intensive than domestic consumption and investment' (Weber et al. 2008).

${ }^{16}$ See Aldy, Orszag, and Stiglitz (2001).

${ }^{17}$ As noted above, India is still below the commonly-suggested target of 2-2.5 tonnes of $\mathrm{CO}_{2}$ equivalent emissions per head.

${ }^{18}$ Thomas Bruckner et al. discuss issues about nuclear energy, and also coal use and CCS, in this volume.
} 
Second, China (and India and others) will continue to exploit their enormous coal reserves. So we urgently need research and development on low cost Carbon Capture and Storage (CCS) technologies to remove coal plants' emissions. The UK government is right to subsidise a demonstration CCS plant. ${ }^{19}$ It should probably subsidise several. It is also right to focus on developing technology can be retrofitted to traditional plants. China is building one such plant every five days.

Crucially, however, it will always be cheaper to burn coal (and oil and gas) without CCS than with it. We can encourage developing countries to use CCS through a revised Clean Development Mechanism or - better - by including them in an emissions trading scheme that allocates them enough permits that they make money by participating. But Western electorates will only be willing to transfer limited resources to the developing world. There may also be problems monitoring whether CCS technology is being used as claimed, or with leakage from the storage sites.

So CCS alone will not suffice. ${ }^{20}$ Only clean energy sources that are cheaper than those currently available are likely to prevent further emissions growth in the developing world. $^{21}$

If large-scale nuclear power is politically unacceptable, substantial investment in clean energy R\&D is the only alternative. But the private sector will not do this unaided.

Businesses know that when an innovation is sufficiently important, the innovator gets little of the benefit: the developers of drugs for AIDS, and of vaccines for Anthrax and bird flu were threatened with compulsory licenses in many countries (including in the United States) until they 'voluntarily' licensed their innovations cheaply. The difficulties of getting effective patent protection in the first place (so any innovator would fear being copied, and forced to compete with imitators), the riskiness of much energy R\&D, and the large scale of some of the necessary investments (for example,

\footnotetext{
${ }^{19}$ See http://www.berr.gov.uk/whatwedo/energy/sources/sustainable/ccs/ccs-demo/page40961.html

${ }^{20}$ A dramatically cheaper 'geoengineering' solution that sucks $\mathrm{CO}_{2}$ directly from the sea or the atmosphere (so, in effect, making all existing energy sources clean) might suffice. Here too, public money for R\&D is essential for the reasons discussed below.

${ }^{21}$ For example, further development of solar energy may be a particularly promising avenue for the substitution of dirty energy -- see the discussion by Walter Kohn in this volume.
} 
research into fusion) are further reasons why business is reluctant to undertake the needed R\&D without subsidies. ${ }^{22}$

So it is catastrophic that - as the Stern Report emphasized ${ }^{23}$ - public expenditure on energy $R \& D$ has been falling in most countries over the last 30 years, and it is shameful that most of Europe spends a much smaller fraction of its GDP on public energy R\&D even than the USA and Japan. The UK is one of the worst offenders.

\section{Publicly-funded R\&D}

Calling for more publicly-funded R\&D raises two questions: How should the funds be raised? And how should they be targeted?

Countries should agree that each of them will support more R\&D if the others do likewise, thus increasing all countries' incentives to do this. Furthermore, if the EU's cap and trade emissions permits were all auctioned, rather than largely given away free, ${ }^{24}$ the expected revenues would be at least 30 billion euros per year (based on current carbon prices ${ }^{25}$ ) - and could be greater still if the scheme were expanded to include more sources of emissions. ${ }^{26}$ A large fraction of the auction proceeds could

\footnotetext{
${ }^{22}$ Even if these problems did not apply, private enterprise would do less innovation than would be socially optimal, because - as argued above - it is implausible that the international community will make a credible commitment to set a price for greenhouse-gas emissions that equals their full social costs.

${ }^{23}$ See figure 16.3 of the Stern Review, which draws on data from the IEA.

${ }^{24}$ The permits will mostly be given out to companies free until 2012. (See note 14 for the (lack of) justification for this.) As of December 2008, the EU plans to auction $100 \%$ of permits for electricity generation in 2013, aside from some 'derogations'; it plans to auction $20 \%$ of industrial permits then, rising to $70 \%$ by 2020 , for industries not considered at risk of 'carbon leakage'; see EU (2008).

${ }^{25}$ The number of emissions allowances (EUAs) to be allocated annually (2083 million tonnes $\mathrm{CO}_{2}$ in the period 2008-2012; see European Commission (2007) and Committee on Climate Change report (2008, p151)) multiplied by their market price (€15.30 at mid-December 2008, see

http://www.pointcarbon.com/) yields about $€ 30$ billion. Note, however, that this carbon price is low, relative both to the recent past and to some expectations. (The Committee on Climate Change report (2008, p169) uses a carbon price of $€ 51 / \mathrm{tCO}_{2}$ in 2020 based on 'the assumption of an EU 30\% GHG target and central fossil fuel prices [which] corresponds to the post global deal world [it is] expecting and planning for'.)

${ }^{26}$ As of December 2008, it seems likely that the EU's Emissions Trading Scheme will cover aviation for the first time from 2012 (European Commission, 2006).
} 
and should be hypothecated to R\&D funding; ${ }^{27}$ similar approaches should be taken outside the EU.

Economics has less to say about how best to spend the money. ${ }^{28}$ It seems that even with a clear, and apparently relatively easily achievable goal, innovative processes can be highly unpredictable. ${ }^{29}$ That suggests spreading the money into a variety of different hands and approaches. Existing funding at both national and EU level should be increased, especially for basic science (and science teaching). ${ }^{30}$ There is probably a greater role for publicly-funded prizes for specific achievements than is now common - witness the success of the XPrizes. ${ }^{31}$ And the vagueness of these remarks demonstrates an urgent need for research into the economics of innovation!

\section{Conclusion}

More R\&D into clean energy is probably the highest priority of all. There are other priorities too, of course. In particular, curbing deforestation is cheap and costeffective, and has the collateral benefit of preserving biodiversity. But finding a clean energy source that is cheaper than those currently available is the only politically plausible way of curbing growth in developing nations' emissions.

\footnotetext{
${ }^{27}$ Minister Gabriel of Germany makes the welcome statement in this volume that Germany intends to hypothecate all its auction revenues to its 'Climate Initiative', to subsidise schemes in 'sustainable energy systems, adaptation and sustainable forest management projects in developing countries'. As of December 2008, the EU plans to hypothecate the proceeds from the sales of 200 million emissions allowances in the post-2012 period to the development of CCS and renewable energy sources; see EU (2008).

Hypothecation violates economic orthodoxy, of course, but it seems consistent with practical politics in this context.

${ }^{28}$ See, however, the useful discussion in Arrow et al. (2008).

29 For example, Bresnahan (2008) documents that even though e-commerce was an obvious application of the PC, many of the obvious players -- including Citibank who invested \$300 million, and an IBM-Sears-Roebuck-CBS joint-venture -- made very large R\&D investments in unsuccessful attempts to develop it; e-commerce only eventually arrived after academics-turned-entrepreneurs developed the browser.

${ }^{30}$ The greatest danger is that special interests' lobbying activities will misdirect funding to particular firms, industries, etc. One way to reduce the likelihood of this is to allocate funding through institutions such as the National Science Foundation in the US, and the Royal Society and the Engineering and Physical Sciences Research Council, etc., in the UK.

31 The prototype is the Ansari X Prize, which offered $\$ 10$ million to the team who could most convincingly pioneer space tourism. This reportedly galvanised substantial private sector investment which resulted in overcoming the technological challenges (Kalil (2006), p. 5-7, see also Masters and Delbecq (2008)). Further prizes have been announced in genomics, environmentally friendly vehicles and moon transportation (see http://www.xprize.org/ ). Publicly-funded prizes can be in the form of government purchase guarantees.
} 
This article is a revised and updated version of my October 2007 talk to the Potsdam Global Sustainability Symposium (which drafted the "Potsdam Declaration" presented to the UN Climate Change Conference in Bali).

A shorter version of the talk was published in VoxEU, 13 December, 2007.

\section{REFERENCES}

Aldy, J.E., Orszag, P.R. and Stiglitz, J.E. (2001). Climate Change: An Agenda for Global Collective Action., Paper prepared for the conference on The Timing of Climate Change Policies, Pew Center on Global Climate Change, Washington, D.C., October 2001.

Angelsen A. and Kaimowitz D. (1999). Rethinking the Causes of Deforestation: Lessons from Economic Models, World Bank Research Observer, 14, Number 1, pp. 73-98

Arrow, K.J. et at (2008). A Statement on the Appropriate Role for Research and Development in Climate Policy. Reg-Markets Center, AEI Center for Regulatory and Market Studies. Available from http://www.reg-markets.org

M. Auffhammer and R. Carson, (2008). Forecasting the Path of China's CO2 Emissions Using Province Level Information. Journal of Environmental Economics and Management, 55, Issue 3, Pages 229-247.

Binmore, K. and Klemperer, P. (2002). The Biggest Auction Ever: the Sale of the British 3G Telecom Licenses. Economic Journal, 112, C74-C96.

Bresnahan, T. (2008). Entrepreneurs, Large Firms and Innovation. Clarendon Lectures, Oxford.

Bruckner, T. et al. (2008). Robust Options for Decarbonisation. In this volume.

Chen, S. and Ravallion, M. (2008) China is poorer than we thought, but no less successful in the fight against poverty. World Bank Policy Research Working Paper 4621

Committee on Climate Change Report (2008). Building a low-carbon economy - the UK's contribution to tackling climate change. Norwich: TSO; available from http://www.tsoshop.co.uk

Desai, N. (2008). Climate Change, Poverty Eradication and Sustainable Development. In this volume.

Ecofys (2008). Factors underpinning future action - country fact sheets 2008 update. Report prepared for the UK Department of Energy and Climate. Available from http://www.ecofys.com/com/publications/reports_books.asp 
European Commission (2006). Proposal for a Directive of the European Parliament and of the Council amending Directive 2003/87/EC so as to include aviation activities in the scheme for greenhouse gas emission allowance trading within the Community. Available at http://ec.europa.eu/prelex/detail_dossier_real.cfm?CL=en\&DosId=195168

European Commission (2007). Emissions trading: Commission adopts amendment decision on the Slovak National Allocation Plan for 2008 to 2012. IP/07/1869. Brussels, 7 December 2007

EU (2005). Climate Change: Medium and longer term emission reduction strategies, including targets with Council conclusions. The Council of the European Union, Document No. 7242/05. Brussels, 11 March 2005

EU (2008). Energy and climate change - Elements of the final compromise. EU document, December 2008, available at http://ec.europa.eu/climateaction/key_documents/index_en.htm

Fries S. (2008). Allocating emission allowances: towards a sustainable approach. Oxonomics 3, 36-39.

Gabriel, S. (2008). The German Offer. In this volume.

Hansen, J. et al. (2008). Target atmospheric CO2: Where should humanity aim? The Open Atmospheric Science Journal, 2, pp. 217-231.

International Monetary Fund (IMF) (2008), Direction of Trade Statistics (DOTS) 10 December 2008, ESDS International, (Mimas) University of Manchester

IPCC (2007). Climate Change 2007: Synthesis Report. Contribution of Working Groups I, II and III to the Fourth Assessment Report of the Intergovernmental Panel on Climate Change [Core Writing Team, Pachauri, R.K and Reisinger, A.(eds.)]. IPCC, Geneva, Switzerland, 104 pp.

Kalil, T. (2006). Prizes for Technological Innovation. Brookings Institution Working Paper.

Keidel, A. (2007). The Limits of a Smaller, Poorer China. Financial Times, November 13.

Klemperer, P. (2004). Auctions: Theory and Practice. Princeton, US: Princeton University Press. (Chinese translation, 2006, Beijing, China: Renmin University Press.)

Klemperer, P. (2007). Why Economists Don't Know All the Answers about Climate Change. Editorial. Financial Times, 11-5-07, p.15, available at http://www.gqq10.dial.pipex.com/PressArticles/Doc3.pdf, and in Britain in 2008, p.20.

Klemperer, P. (2008a). If Climate Sceptics are Right, It is Time to Worry. Editorial. Financial Times, 29-2-08, p.11, available at http://www.gqq10.dial.pipex.com/PressArticles/Doc33.pdf

Klemperer, P. (2008b). Permit Auction will not Affect Prices. Financial Times, 9-6-08, p.10, available at http://www.gqq10.dial.pipex.com/PressArticles/EmissionPermitAuctions.pdf

Kohn, W. (2008). The Power of the Sun. In this volume.

Lambin, E.F. et al. (2001). The causes of land-use and land-cover change: moving beyond the myths. Global Environmental Change, 11, Issue 4, December 2001, 261-269. 
Masters, W.A and Delbecq, B. (2008). Accelerating Innovation with Prize Rewards: History and Typology of Technology Prizes and a New Contest Design for Innovation in African Agriculture. IFPRI Discussion Paper.

Prinn, R. et al. (2008). The Influence on Climate Change of Differing Scenarios for Future Development Analyzed Using the MIT Integrated Global System Model. MIT Joint Program on the Science and Policy of Global Change, Report No. 163, Sep 2008.

Schellnhuber, H.J. et al., Eds. (2006). Avoiding Dangerous Climate Change. Cambridge, Cambridge University Press.

Shell (2008), Shell Energy Scenarios to 2050 at http://wwwstatic.shell.com/static/aboutshell/downloads/our_strategy/shell_global_scenarios/SES\%20boo klet $\% 2025 \% 20$ of $\% 20 J u l y \% 202008$.pdf

Stern, N. (2007). The economics of climate change: the Stern review. Cambridge: Cambridge University Press.

Stern, N. (2008). Global Deal. In this volume.

United Nations (UN) (2007), United Nations Common Database, UNESCO estimates, 22 November 2007, ESDS International, (Mimas) University of Manchester

UNFCCC (1992). United Nations Framework Convention on Climate Change, international treaty, available at http://unfccc.int/essential_background/convention/background/items/1362.php

Weber, C.L. et al. (2008). The contribution of Chinese exports to climate change. Energy Policy 36, Issue 9, September 2008, 3572-3577.

World Bank (2008), World Bank World Development Indicators, 23 May 2008, ESDS International, (Mimas) University of Manchester

[Note to typesetter: note 24 references note 14 with current numbering.] 